Ettredge, Michael. (2011) The Effects of Company Size, Corporate Governance Quality, and Bad News on Disclosure Compliance. Review of Accounting Studies. Publisher's Official Version: <http://link.springer.com/article/10.1007\%2Fs11142-011-9153-8>. Open Access Version: http://kuscholarworks.ku.edu/dspace/.

[This document contains the author's accepted manuscript. For the publisher's version, see the link in the header of this document.]

\title{
The Effects of Firm Size, Corporate Governance Quality, and Bad News on Disclosure Compliance
}

\author{
By Michael L. Ettredge, Karla Johnstone, Mary Stone, Qian Wang \\ University of Kansas, University of Wisconsin-Madison, University ofAlabama, lowa State University \\ Paper citation:
}

Ettredge, Michael. (2011) The Effects of Company Size, Corporate Governance Quality, and Bad News on Disclosure Compliance. Review of Accounting Studies.

\section{Keywords:}

Auditor change $\cdot$ Compliance $\cdot$ Mandatory disclosure $\cdot$ SEC staff comment letters . Size-based regulation

\begin{abstract}
:
Motivated by calls for increased compliance, size-based regulation, and continued exemption of small firms from internal control reporting requirements, we assess the incremental effects of firm size, corporate governance quality, and bad news on disclosure compliance. We examine compliance with the disclosure requirements of an SEC-mandated filing that requires no computations or complex judgments, but is non-routine and may reveal value-decreasing information (i.e., bad news) that otherwise would not become public. The disclosures studied are those that firms provide in Form 8-K Item 4 when changing external auditors. We find that non-compliant firms have lower quality corporate governance and less need for external financing, but are not smaller than compliant control firms. Additional analyses indicate that compliance is negatively associated with bad news.
\end{abstract}




\title{
The effects of firm size, corporate governance quality, and bad news on disclosure compliance
}

\author{
Mike Ettredge * \\ University of Kansas \\ Karla Johnstone \\ University of Wisconsin - Madison \\ Mary Stone \\ University of Alabama \\ Qian Wang \\ Iowa State University \\ *School of Business \\ 1300 Sunnyside Ave. \\ Lawrence, KS 66045-7585 \\ Tel. (785) 864-7537 \\ mettredge@ku.edu
}

September 2010

We appreciate the comments and suggestions provided by workshop participants at the University of Alabama, University of Kansas, Central Florida University, University of Wisconsin School of Business, and the 2007 annual meeting of the American Accounting Association. Johnstone acknowledges support from the University of Wisconsin Arthur Andersen Center for Financial Reporting and Control. 


\title{
The effects of firm size, corporate governance quality, and bad news on disclosure compliance
}

\begin{abstract}
Motivated by calls for increased compliance, size-based regulation, and continued exemption of small firms from internal control reporting requirements, we assess the incremental effects of firm size, corporate governance quality, and bad news on disclosure compliance. We examine compliance with the disclosure requirements of an SEC-mandated filing that requires no computations or complex judgments, but is nonroutine and may reveal value-decreasing information (i.e., bad news) that otherwise would not become public. The disclosures studied are those that firms provide in Form 8K Item 4 when changing external auditors. We find that non-compliant firms have lower quality corporate governance and less need for external financing, but are not smaller than compliant control firms. Additional analyses indicate that compliance is negatively associated with bad news.
\end{abstract}

Keywords: Auditor change $\cdot$ Compliance $\cdot$ Mandatory disclosure $\cdot$ SEC staff comment letters $\cdot$ Size-based regulation 


\section{The effects of firm size, corporate governance quality, and bad news on disclosure compliance}

\section{Introduction}

This paper investigates the roles of firm size, corporate governance quality, and bad news in determining compliance with disclosure requirements. The investigation is motivated by Sarbanes-Oxley's mandate to increase efforts to ensure compliance with accounting and reporting requirements (KPMG International 2004, 2005), by assertions that small businesses lack the accounting skills and resources needed to comply with some disclosure requirements (Securities and Exchange Commission (SEC) Advisory Committee on Smaller Public Companies 2006), by continued debate about the value of corporate governance to small firms, and by the paucity of research on factors affecting disclosure compliance.

Proponents of scale-based regulation argue that because compliance costs are disproportionately higher for small firms, such firms should be exempted from certain disclosure requirements. ${ }^{1}$ The posited higher cost of compliance suggests that small firms would be less likely to comply with disclosure requirements regardless of whether the news to be provided reflects favorably or unfavorably on the firm and ignores the role high quality corporate governance can play.

\footnotetext{
${ }^{1}$ Recommendations made by the Advisory Committee on Smaller Public Firms are reflected in the SEC's (2008) Final Rule: Smaller Reporting Companies Regulatory Relief and Simplification Act. This amendment to the Securities Act of 1933 and the Securities Exchange Act of 1934, which became effective in February 2008, expands the number of firms that qualify for scaled disclosure and streamlines regulation by moving scaled disclosure requirements from Regulation S-B into Regulation S-K. It also allows smaller reporting firms to comply with scaled financial and nonfinancial disclosure requirements on an item-byitem basis.
} 
Ettredge, Michael. (2011) The Effects of Company Size, Corporate Governance Quality, and Bad News on Disclosure Compliance. Review of Accounting Studies. Publisher's Official Version: <http://link.springer.com/article/10.1007\%2Fs11142-011-9153-8>. Open Access Version: http://kuscholarworks.ku.edu/dspace/.

To provide evidence on factors that affect disclosure compliance, we examine compliance with a straight-forward disclosure requirement: to report the circumstances of an auditor change. The setting provides a base case that does not require knowledge of any commercial arrangement, estimation of an amount, or judgment of materiality. All that is required is that management states the facts concerning the (infrequent) occurrence of an auditor change. The disclosures are considered relevant to investors because an auditor change raises questions about the reliability of financial statement information (Knapp and Elikai 1988).

In two analyses of compliance with SEC auditor change filing requirements, Schwartz and Soo $(1995,1996)$ focus on compliance with timely filing requirements (i.e., do firms file within the allowed time period), not on compliance with requirements that specify the content of auditor change filings. At the time of their studies, disclosures about the reasons for auditor change were voluntary. Schwartz and Soo's results indicate that late filing of Form 8-K Item 4 ("8-K Item 4") is negatively associated with firm size and positively associated with corporate financial distress. We find that size and financial condition have no incremental explanatory power in our study of compliance with 8-K Item 4 disclosure content requirements, and there is an association between corporate governance quality and disclosure compliance.

SEC Regulation S-K, Item 304(a) requires that firms report the termination of association with an external auditor in 8-K Item 4, including information on client and auditor circumstances surrounding the termination. Unlike some required disclosures, information about auditor changes omitted from 8-K Item 4 filings will not necessarily become publicly available through alternative sources. Evidence of the importance of 8-K 
Ettredge, Michael. (2011) The Effects of Company Size, Corporate Governance Quality, and Bad News on Disclosure Compliance. Review of Accounting Studies. Publisher's Official Version: <http://link.springer.com/article/10.1007\%2Fs11142-011-9153-8>. Open Access Version: http://kuscholarworks.ku.edu/dspace/.

Item 4 filings and the negative market reaction to bad news disclosed in them (e.g., DeFond et al. 1997; Krishnan and Krishnan 1997; Wells and Louder 1997; Hackenbrack and Hogan 2002; Whisenant et al. 2003; Sankaraguruswamy and Whisenant 2004) provides an alternative (to size) explanation for firm failures in disclosure compliance: suppression of bad news.

We focus our initial analysis on firms' auditor change disclosures at 128 firms that convey bad news. We compare firm size and the quality of corporate governance for firms that disclosed (versus failed to disclose) bad news about the circumstances of auditor changes. We identify firms' failures to disclose bad news using SEC staff comment letters filed between May 2005 and April 2007. ${ }^{2}$ We match firms that failed to comply with disclosure requirements with firms that have the same types of bad news but that complied with disclosure requirements. Our results indicate that, for this sample, firms that failed to properly disclose bad news had weaker corporate governance and relied less on external financing than those that properly disclosed bad news. Firm size is not a significant determinant of bad news disclosure.

We test the sensitivity of these results by comparing all firms identified from SEC comment letters as failing to provide all required auditor change disclosures with a sample of fully disclosing firms $(\mathrm{N}=161)$ matched by date of auditor change. The comparison includes proxies for firm size, corporate governance, bad news, and control variables. Results show that firms that failed to properly disclose bad news have weaker corporate governance, are less likely to have a departing Big 4 auditor, are more likely to

\footnotetext{
${ }^{2}$ SEC Comment letters were first posted to the SEC EDGAR website on May 12, 2005. The majority of the originally posted letters relate to 8 -K Item 4 omissions.
} 
Ettredge, Michael. (2011) The Effects of Company Size, Corporate Governance Quality, and Bad News on Disclosure Compliance. Review of Accounting Studies. Publisher's Official Version: <http://link.springer.com/article/10.1007\%2Fs11142-011-9153-8>. Open Access Version: http://kuscholarworks.ku.edu/dspace/.

have certain types of bad news (lack of board approval for the auditor change and clientauditor disagreements), and are similar in size to firms that properly disclosed bad news.

Our paper contributes to the literature in several ways. First, our results do not support the contention that firm size per se reduces compliance with straight-forward disclosure obligations. Our results suggest that firm compliance is positively associated with the quality of corporate governance, and negatively associated with the disclosure of certain types of bad news. The positive relation between compliance and corporate governance demonstrates the importance of strong corporate governance even in small firms. This importance is further supported by our results showing that small firms with high quality corporate governance are more likely to disclose bad news. These results suggest that governance improvements at small firms would improve compliance with disclosure requirements even in the presence of bad news.

Second, we provide evidence on compliance with mandatory disclosure requirements (Schwartz and Soo 1995; Ettredge et al. 2001) using SEC staff objections to firm disclosures in comment letters posted on the SEC website. A number of studies develop and test explanations for discretionary disclosures (e.g., Healy and Palepu 2001; Graham et al. 2005), and with SEC filing deadline compliance (e.g., Schwartz and Soo 1996; Ettredge et al. 2006). ${ }^{3}$ Studies of why managers fail to comply with seemingly straight-forward disclosure requirements likely are missing because of the lack of information about disclosure violations prior to the public release of SEC comment letters

\footnotetext{
${ }^{3}$ Other studies have investigated tax compliance (e.g., Slemrod 1992; Andreoni et al. 1998; Davis et al. 2003; and Martinez-Vasques and Rider 2005). These studies consider the tax decisions of individuals, not corporations. Hammersley et al. (2010) examine firms that fail to comply with requirements to remediate previously identified internal control deficiencies. They are more concerned with documenting the consequences of noncompliance than the reasons for noncompliance.
} 
Ettredge, Michael. (2011) The Effects of Company Size, Corporate Governance Quality, and Bad News on Disclosure Compliance. Review of Accounting Studies. Publisher's Official Version: <http://link.springer.com/article/10.1007\%2Fs11142-011-9153-8>. Open Access Version: http://kuscholarworks.ku.edu/dspace/.

in 2005. Our results reveal the factors associated with disclosure compliance in one context and are a first step to determining ways to increase the rate of compliance.

Our third contribution relates to the distinction between good (or neutral) news and bad news in a disclosure compliance setting. We provide evidence suggesting that managers opportunistically omit disclosures that previous research indicates are viewed as bad news by investors; that is, managers behave opportunistically in determining how to comply with disclosure requirements. These results complement evidence that managers behave opportunistically in making discretionary accounting choices (see e.g., Healy and Palepu 2001; Kothari et al. 2009). While strategic behavior might be expected in discretionary disclosure settings, it is perhaps surprising that managers are willing to risk the disapproval of the SEC by partial compliance with $8-\mathrm{K}$ regulation. Thus, our results provide justification for continued monitoring of mandatory disclosures, especially 8 -K Item $4 \mathrm{~s}$.

The next section of the paper describes the SEC staff comment letter database and 8-K Item 4 disclosure requirements. Section 3 presents our theory, conceptual constructs, and expected associations. Section 4 discusses the sample, models and variables. Sections 5 and 6 report the results. Section 7 discusses limitations, summarizes, and concludes.

\section{The SEC comment letter database and Form 8-K Item 4}

We identify firms that failed to comply with 8-K Item 4 disclosure requirements using SEC staff comment letters that assert that submitted filings do not contain all required disclosure items. SEC staff comment letters form one foundation for the SEC's enforcement process by providing incentives for managers and auditors to avoid both 
Ettredge, Michael. (2011) The Effects of Company Size, Corporate Governance Quality, and Bad News on Disclosure Compliance. Review of Accounting Studies. Publisher's Official Version: <http://link.springer.com/article/10.1007\%2Fs11142-011-9153-8>. Open Access Version: http://kuscholarworks.ku.edu/dspace/.

unacceptable practices and the violation of accounting principles or disclosure regulations. Each year the SEC staff (Divisions of Corporation Finance and Investment Management) reviews filed documents (such as registration statements relating to initial public offerings, 8-Ks, 10-Qs and 10-Ks), evaluates them for compliance with disclosure regulations, and sends comment letters to selected firms, ${ }^{4}$ typically indicating areas where the staff believes disclosure should be improved. Management can respond to a comment letter by making the recommended changes, suggesting alternative approaches, or presenting an argument that the current disclosure is appropriate. If the registrant's action or argument does not satisfy the SEC staff, the matter may be forwarded to the enforcement division. $^{5}$

In response to requests for disclosure of staff comment letters under the Freedom of Information Act, the SEC announced on June 24, 2004 (SEC 2004) that it planned to begin releasing its staff comment letters. The SEC began posting the comment letters at its EDGAR web site on May $12,2005 .^{6}$ The majority of the letters initially posted relate to 8-K Item 4 matters, with particular focus on firms' failures to explain auditor changes or to address omissions in information relating to auditor changes (Martinek 2005). ${ }^{7}$

\footnotetext{
${ }^{4}$ A 2007 interview with an SEC staff member provided the following information about the comment letter process. The staff undertakes several types of reviews: full review, financial statement review (including footnotes), and targeted (limited scope) reviews. The subjects of targeted reviews change over time. The criteria for selection of filings for review are not made public because doing so might prompt firms to take steps to avoid review. The SEC neither confirms nor denies that the SEC staff reviews all 8-K Item $4 \mathrm{~s}$ that are filed. However, we examine 2258 -K Item $4 \mathrm{~s}$ submitted by control firms that did not receive SEC staff comment letters. (See discussions of control samples in Sections 4.1 and 6.2) All contained the required disclosures. We are confident that the SEC review process does not result in failure to challenge significant numbers of 8 -K Item $4 \mathrm{~s}$ that lack required disclosures.

${ }^{5}$ A May 2007 interview with an SEC staff member indicated that if a registrant does not respond to a comment letter, a staff member follows up with a phone call. Historically, non-response has not been a problem. Referral to the enforcement division is not common because registrants usually acquiesce to the SEC's suggestions.

${ }^{6}$ Audit Analytics now provides a database of SEC comment letters.

${ }^{7}$ A May 2007 interview with an SEC staff member confirmed that the SEC intentionally posted letters dealing with auditor change disclosures first, as a trial effort.
} 
Ettredge, Michael. (2011) The Effects of Company Size, Corporate Governance Quality, and Bad News on Disclosure Compliance. Review of Accounting Studies. Publisher's Official Version: <http://link.springer.com/article/10.1007\%2Fs11142-011-9153-8>. Open Access Version: http://kuscholarworks.ku.edu/dspace/.

Regulation S-K, Item 304(a), requires that 8-K Item 4 filings report the termination of association with an external auditor, including information on client and auditor circumstances surrounding the change. Prior research documents the importance of 8-K Item 4 filings as a whole, and indicates that certain disclosures about the circumstances of auditor changes are viewed as bad news by investors (DeFond et al. 1997; Krishnan and Krishnan 1997; Wells and Loudder 1997; Hackenbrack and Hogan 2002; Whisenant et al. 2003; Sankaraguruswamy and Whisenant 2004).

Information about the circumstances of an auditor change omitted from 8-K Item 4 will not necessarily come to light via other means. Suppose, for example, that an $8-\mathrm{K}$ Item 4 states that a firm "no longer is associated with" an auditor when, in fact, the auditor resigned. The resignation might become public knowledge if the SEC staff noticed that the 8-K Item 4 did not state, as required by Regulation S-K Item 304, whether the former accountant resigned, declined to stand for re-election or was dismissed, or if the former auditor noticed the omission, and communicated it to the client in its letter commenting on the contents of the client's 8-K Item 4. That letter, required by Regulation S-K Item 304(a)(3), should be included by the client in its 8-K Item 4 submission to the SEC. However, the auditor might not detect such an error and, if it did, the client might fail to include the auditor's letter with the 8-K Item 4 . If the SEC staff does not detect omitted information when the initial 8-K Item 4 is filed, there is no subsequent event that will with certainty reveal the information to the public.

\section{Theory, constructs, and expected associations}

We posit that firm size, corporate governance quality, and adverse information about an auditor change are determinants of full compliance with the requirements of an 8-K Item 
Ettredge, Michael. (2011) The Effects of Company Size, Corporate Governance Quality, and Bad News on Disclosure Compliance. Review of Accounting Studies. Publisher's Official Version: <http://link.springer.com/article/10.1007\%2Fs11142-011-9153-8>. Open Access Version: http://kuscholarworks.ku.edu/dspace/.

4 filing. The dependent variable captures whether a client's 8-K Item 4 contains all required information. ${ }^{8}$ Below, we describe the explanatory constructs and discuss their expected effects on disclosure compliance.

\section{$\underline{\text { Firm Size }}$}

The SEC has expressed concern that smaller registrants lack sufficient qualified personnel to deal with disclosure requirements. ${ }^{9}$ For example, in March 2005, the SEC formed an Advisory Committee on Smaller Public Companies, which recommended smaller firms not be subject to further acceleration of Form 10-Q and 10-K filing dates, "because of the lack of capacity... of internal compliance personnel and external professional advisors to smaller public firms" (SEC Advisory Committee on Smaller Public Companies 2006). In 2008, the SEC amended Regulation S-K to expand the number of firms that qualify for scaled (by size) disclosure requirements (SEC 2008). In 2010 the Dodd-Frank Act (Public Law No: 111-203) provided smaller (non-accelerated) filers with permanent exemption from Section 404 of the Sarbanes-Oxley Act of 2002. ${ }^{10}$ We expect firm size to be positively associated with 8-K Item 4 disclosure compliance.

\section{Corporate governance quality}

\footnotetext{
${ }^{8}$ The primary method for initially identifying non-compliance is firm receipt of an SEC staff comment letter. We scrutinize 8 -K Item $4 \mathrm{~s}$ of all non-compliant firms to determine the nature of the information omitted. We study the $8-\mathrm{K}$ Item $4 \mathrm{~s}$ of all matching, compliant firms to ensure that all information items are present.

${ }^{9}$ The SEC currently designates firms with less than $\$ 75$ million public float as smaller registrants. The previous threshold was less than \$25 million in public common equity and less than \$25 million in annual revenue. The change in threshold is expected to increase the number of smaller reporting firms to 4,976 from 3,395 , an increase of $47 \%$. Firms without calculable public float are considered small reporting firms if the previous year's revenues were less than $\$ 50$ million.

${ }^{10}$ Non-accelerated filers are still required to perform their own assessments of internal control and those assessments are now subject to liability under securities laws. However, non-accelerated filers need not provide an external auditor's Section 404 internal control assessment (KPMG 2010).
} 
Ettredge, Michael. (2011) The Effects of Company Size, Corporate Governance Quality, and Bad News on Disclosure Compliance. Review of Accounting Studies. Publisher's Official Version: <http://link.springer.com/article/10.1007\%2Fs11142-011-9153-8>. Open Access Version: http://kuscholarworks.ku.edu/dspace/.

Corporate governance is an important determinant of disclosure compliance. The Committee of Sponsoring Organizations of the Treadway Commission (COSO 2004) notes that the board of directors is responsible for monitoring firm risk control activities, including reporting efforts. ${ }^{11}$ The audit committee also has a direct role in external reporting. Karamanou and Vafaes $(2005,453)$ state that "empirical evidence is broadly consistent with the notion that effective corporate governance is associated with higher financial disclosure policy." Research has established a positive relation between board independence and practices consistent with high quality corporate governance (Weisenbach 1988, Brickely et al. 1994), and between financial expertise and other audit committee characteristics and the effectiveness of monitoring financial reporting (Menon and Williams 1994; Abbott et al. 2004; Carcello and Neal 2003; Bedard et al. 2004). We use measures of board quality and audit committee quality as proxies for governance quality. We expect higher quality board and audit committee governance to be positively associated with 8-K Item 4 disclosure compliance.

Both Congressional mandate and prevailing business practice hold CFOs accountable for the quality of financial information issued by their corporations (Geiger and North 2006). Research links CFO quality and internal control quality (Li et al. 2010). Because the CFO typically is responsible for initiating non-routine filings (e.g., Forms 8$\mathrm{K}$ ) as well as routine filings (e.g. Forms $10-\mathrm{K}$ and 10-Q), we expect CFOs with more experience to be positively associated with $8-\mathrm{K}$ Item 4 disclosure compliance. ${ }^{12}$

\footnotetext{
${ }^{11}$ The enterprise risk management process, as defined by COSO, is designed to achieve (among other objectives) "the reliability of the entity's reporting including both internal and external reporting of financial and non-financial information" $(2004,124)$.

${ }^{12} \operatorname{COSO}(2004,87)$ states that the CFO "influences the design, implementation, and monitoring of the firm's reporting systems." According to Deloitte \& Touche's CFO Management Framework (D\&T 2006), the CFO's finance department should "prepare accurate, validated reporting to meet statutory, SEC, and shareholder needs in a timely fashion."
} 


\section{$\underline{\text { Size of external auditor }}$}

The identity of the departing external auditor also can affect disclosure compliance.

There is substantial evidence that audits by larger (Big 4) firms are of higher quality (see Francis 2004 for a review). The largest accounting firms should have greater knowledge of disclosure and filing requirements regarding auditor changes, and we expect these audit firms to share such knowledge with their clients (Ettredge et al. 2001). Thus, we expect the existence of a departing Big 4 auditor (compared to a departing non-Big 4 auditor) to be positively associated with 8 -K Item 4 disclosure compliance.

\section{Bad news in 8-K Item 4}

Regulation S-K, Subpart 229.304, requires that 8-K Item 4s disclose the termination of association with an external auditor, including information that would be considered bad news: (1) whether the former auditor was dismissed, resigned, or declined to stand for reelection, (2) whether the audit report for either of the past two years contained an adverse opinion or a disclaimer of opinion, or was qualified or modified as to uncertainty, audit scope, or accounting principles; including the nature of each such adverse opinion, disclaimer of opinion, modification, or qualification, (3) whether the board of directors approved the decision to change auditors, (4) whether there were any disagreements with the former auditor, (5) whether there were any "reportable events", (6) whether the client consulted with a new auditor regarding application of accounting principles to a specified transaction, or regarding the type of audit opinion the client might receive, or about any disagreement or reportable event, and/or (7) whether the client provided the former 
Ettredge, Michael. (2011) The Effects of Company Size, Corporate Governance Quality, and Bad News on Disclosure Compliance. Review of Accounting Studies. Publisher's Official Version: <http://link.springer.com/article/10.1007\%2Fs11142-011-9153-8>. Open Access Version: http://kuscholarworks.ku.edu/dspace/.

auditor with a copy of the disclosures it intended to make in 8-K Item 4. Items (6) and (7) occur very infrequently (bad news omission of such events occurs less than one percent of the time), so we do not code these disclosures as bad news.

Previous research analyzes market responses to auditor change disclosures. For example, Schwartz and Soo's (1995) analysis of auditor changes suggests that reporting delays may reflect management's attempt to suppress the negative information revealed by auditor changes. A number of studies report negative market reactions to SECmandated disclosures about the circumstances of auditor changes. Wells and Loudder (1997) document a negative price reaction to disclosures of auditor resignation. A negative price reaction may reflect the market's perception that auditor resignation is associated with litigation risk, and is viewed as a warning signal about the quality of the firm's financial reporting (Krishnan and Krishnan 1997). Disclosures of reportable events indicating problems with financial statement reliability are also associated with negative stock price reactions, while those related only to internal control events are not (Whisenant et al. 2003). Smith (1988) provides additional evidence of negative market reaction to auditor change bad news. Managers with knowledge of adverse circumstances associated with auditor changes have disincentives to disclose that information. We therefore expect bad news to be negatively associated with 8-K Item 4 disclosure compliance. If failure to comply with mandatory disclosure requirements in 8 -K Item 4 is due to innocuous mistakes, rather than opportunistic omissions, the information omitted from 8 -K Item 4 s should be random rather than disproportionately adverse. ${ }^{13}$

\footnotetext{
${ }^{13}$ A 2006 SEC study of restatements of financial reports found that the majority of errors restated arise from mistakes. The Deputy Chief Accountant of the SEC stated, "Internal-control structures are missing things, corporate-finance staffs are missing things and auditors are missing things" (Reilly 2006). If these factors also are causing 8-K Item 4 errors, our corporate governance quality variables should be positively
} 
Ettredge, Michael. (2011) The Effects of Company Size, Corporate Governance Quality, and Bad News on Disclosure Compliance. Review of Accounting Studies. Publisher's Official Version: <http://link.springer.com/article/10.1007\%2Fs11142-011-9153-8>. Open Access Version: http://kuscholarworks.ku.edu/dspace/.

\section{Samples, models and variables}

\subsection{Test Sample}

The test sample includes firms failing to comply with 8-K Item 4 disclosure requirements disclosed in SEC staff comment letters ${ }^{14}$ posted on the EDGAR web site from May 2005 through April 2007 (486 comment letters issued to 418 firms on 8-K Item 4 issues). Table 1 Panel A describes the disposition of the sample. We delete 134 comment letters that addressed minor matters other than non-disclosure of required information, ${ }^{15} 78$ firms without ticker symbols, and 45 with missing data, resulting in 161 test firms. We use this sample for tests in Section 6. Of those test firms, 97 received comment letters for failing to disclose neutral information (e.g., failure to disclose an auditor dismissal or failure to disclose board approval for the auditor change). Deleting these 97 firms leaves 64 test firms that omitted bad news. We match those 64 test firms with 64 control firms that also reported auditor changes via Form 8-K, but that did not receive SEC comment letters. We use this sample of 128 firms for tests in Section 5 to investigate the effect of firm size, corporate governance, and control variables when bad news circumstances exist. We match each test firm with a control firm that had the same bad news conditions, but that

associated with full disclosure, but bad news auditor-change circumstances should have no explanatory power.

${ }^{14}$ In some cases, the SEC posted firms' response letters at the web site without posting the SEC comment letters that provoked the responses. We include such firms in the sample since the contents of the comment letters are evident from the responses.

${ }^{15}$ Several examples illustrate the nature of these types of matters. Many such examples concern essentially clerical errors, e.g., "your initial filing of the Item 4.01 Form 8-K did not contain the printed name and title of the person signing the report or the date of the report. Please file an amendment to the Form 8-K including this information", and "We read that you appointed Danziger \& Hochman as your new accountants. Please revise your filing to refer to this firm by the complete name under which they have registered with the PCAOB." Other examples seek clarification, e.g., "Please clarify what you mean by 'or any later period' as the statement is vague. The interim period should be specified as the interim period through [date of resignation, declination or dismissal].” 
properly disclosed the bad news and therefore did not receive a comment letter from the SEC. Table 1 Panel B provides information on industry distribution by SIC codes for the sample. The test sample is concentrated in three industries: manufacturing; finance, insurance, and real estate; and services.

[Insert Table 1 about Here]

\subsection{Overview of analyses}

Our primary analysis uses 128 test and control firms to estimate versions of the following model:

$$
\begin{aligned}
\text { FULDISC }= & \mathrm{a}_{0}+\mathrm{a}_{1} \text { SIZE }+\mathrm{b}_{1} G O V 1+\mathrm{b}_{2} \text { GOV2 } \ldots \\
& +\mathrm{b}_{\mathrm{j}} \text { GOVj }+ \text { AUDITOR }+ \text { CONTROLS. }
\end{aligned}
$$

We present definitions and data sources in Table 2. The dependent variable, FULDISC, equals one for control firms that disclosed all required items in the auditor-change 8-K Item 4 and equals zero for test firms that received SEC comment letters. SIZE proxies for firm size. GOV1 through GOVj are proxies for corporate governance quality. We also estimate a second model in which we replace all governance proxies with a summary governance index, GOV. Both models also include the size of the departing auditor (Big 4 or other), plus control variables.

[Insert Table 2 about Here]

\subsection{Explanatory variable definitions}


Ettredge, Michael. (2011) The Effects of Company Size, Corporate Governance Quality, and Bad News on Disclosure Compliance. Review of Accounting Studies. Publisher's Official Version: <http://link.springer.com/article/10.1007\%2Fs11142-011-9153-8>. Open Access Version: http://kuscholarworks.ku.edu/dspace/.

This section describes our measures of bad news items, firm size, corporate governance quality, departing auditor size, and controls. To measure bad news, we determine the client's actual information state, and code an associated dichotomous variable. For control firms, the actual information state is described in the initial 8-K Item 4 disclosure. For test firms, we determine the actual information state by reading corrected 8-K Item $4 \mathrm{~s}(8-\mathrm{K} / \mathrm{A}$ Item $4 \mathrm{~s})$. RESIGN equals one if the former auditor resigned the engagement or declined to continue providing service to the client, and zero otherwise. NOAPPROV equals one if the decision to change auditors was not approved by the board of directors, and zero otherwise. DISAGREE equals one if there were any disagreements with the former auditor, and zero otherwise. EVENT equals one if there were any "reportable events," and zero otherwise. ${ }^{16}$ PRIORGC equals one if the last audit report before the auditor change included a going concern audit opinion, and zero otherwise. In addition to the individual bad news proxies we use $B A D$ as a summary measure in sensitivity tests reported in Sections 6.2 and 6.3. BAD equals one if any of the five auditor change bad news variables is coded as equal to one, and zero otherwise. Thus, $B A D$ measures the presence of bad news, regardless of type. We expect that each of the bad news variables will be negatively associated with disclosure compliance.

Our proxy for firm size is the natural logarithm of the market value of equity, $L N M V$. As a robustness check we use a dichotomous variable, LARGE, which equals one for firms with market value of equity greater than $\$ 75$ million and zero otherwise. We employ this dichotomous variable because the SEC views $\$ 75$ million as a meaningful

\footnotetext{
${ }^{16}$ Under Item 304 of Regulation S-K, reportable events include: (1) the auditor advised the client that internal controls are inadequate, (2) the auditor is unwilling to rely on management's representations, or to be associated with the financial statements, (3) the auditor advised the client of the need to expand the scope of the audit, and/or (4) the auditor advised the client that information has come to light that materially affects the fairness or reliability of a prior audit report or of the current financial statements.
} 
Ettredge, Michael. (2011) The Effects of Company Size, Corporate Governance Quality, and Bad News on Disclosure Compliance. Review of Accounting Studies. Publisher's Official Version: <http://link.springer.com/article/10.1007\%2Fs11142-011-9153-8>. Open Access Version: http://kuscholarworks.ku.edu/dspace/.

regulatory break-point in public firm size. We expect that size is positively associated with disclosure compliance.

Our proxies for corporate governance quality fall into three categories: (1) board of directors, (2) audit committee, and (3) chief financial officer (CFO). BODINDPCT is the number of independent board of directors divided by the total number of board members. ${ }^{17}$ BODMEET is the number of board meetings annually. We expect both of these variables to be positively associated with disclosure compliance. CEOCHAIR equals one if the client's CEO also serves as chairman of the board, and zero otherwise. We expect this variable to be negatively associated with disclosure compliance. ${ }^{18}$

Regarding audit committee characteristics, $A U D C O M$ equals one if the firm has an audit committee, and equals zero otherwise. ${ }^{19}$ ACMEET equals the number of audit committee meetings held annually. FINEXPRT is equal to the number of financial experts on the audit committee, as defined by the SEC and as designated by the firm. We expect each of these variables to be positively associated with disclosure compliance.

Regarding CFO characteristics, we measure CFO experience as the number of years the CFO has held that position, CFOTENURE, and expect greater experience to be positively associated with disclosure compliance. CFOBOD is equal to one if the CFO is on the board and to zero otherwise. We anticipate that $C F O B O D$ will be negatively associated with disclosure compliance because the CFO's presence may make the board less independent of management with regard to reporting and disclosure. Finally, given

\footnotetext{
${ }^{17} \mathrm{We}$ determine director independence based on firm classifications provided in proxy statements.

${ }^{18}$ This expectation is consistent with the negative association between CEO duality and the high quality governance practice of managerial turnover following restatements (Desai et al. 2006).

${ }^{19} \mathrm{We}$ code audit committee existence rather than percentage of independent audit committee members because our sample includes firms with shares quoted on the OTCBB and Pink Sheets, which are not subject to exchange listing requirements and have not voluntarily created audit committees.
} 
Ettredge, Michael. (2011) The Effects of Company Size, Corporate Governance Quality, and Bad News on Disclosure Compliance. Review of Accounting Studies. Publisher's Official Version: <http://link.springer.com/article/10.1007\%2Fs11142-011-9153-8>. Open Access Version: http://kuscholarworks.ku.edu/dspace/.

the role of CFOs in managing the internal control environment, we include the variable INTCONMW, which equals one if the firm reports an internal control material weakness (under SOX Section 404), and zero otherwise. ${ }^{20}$ We expect that the presence of an internal control material weakness will be negatively associated with disclosure compliance.

We use GOV as a summary measure in an alternative version of model (1). GOV is derived from the nine governance indicator variables. We add one to the value of $G O V$ if the value of BODINDPCT, BODMEET, ACMEET, FINEXPRT or CFOTENURE is larger than the sample median, respectively. We add one to the value of GOV if CEOCHAIR equals zero, if CFOBOD equals zero, if $A U D C O M$ equals one, and if INTCONMW equals zero, respectively. We expect that higher quality corporate governance as indicated by GOV will be positively associated with disclosure compliance.

We measure the effect of the external audit firm using BIG4DEPART, which equals one if the firm is audited by a Big 4 audit firm prior to the auditor change, and zero otherwise. We expect that departing Big 4 auditors are more likely than other audit firms to remind their clients to make complete 8-K Item 4 filings, and are more likely to ensure that the clients follow through. Thus, BIG4DEPART should be positively associated with disclosure compliance.

\subsection{Control variables}

We use two control variables to capture managers' incentives and ability to comply with mandatory disclosure requirements. The first captures firm plans to raise

\footnotetext{
${ }^{20}$ For smaller firms not subject to SOX Section 404, we use internal control information reported under SOX Section 302.
} 
Ettredge, Michael. (2011) The Effects of Company Size, Corporate Governance Quality, and Bad News on Disclosure Compliance. Review of Accounting Studies. Publisher's Official Version: <http://link.springer.com/article/10.1007\%2Fs11142-011-9153-8>. Open Access Version: http://kuscholarworks.ku.edu/dspace/.

capital externally, EXTFIN. It is computed following Bradshaw et al. (2006) as the sum of equity financing and debt financing in the subsequent fiscal year, scaled by total assets. Because firms subject to greater scrutiny by investors and regulators have more incentives to invest in governance infrastructure, and greater incentives to comply, we expect a positive association between external financing and disclosure compliance. The second control variable measures firms' financial health. Financially distressed firms likely have less ability to comply with disclosure requirements because they devote their scarce monetary resources and managerial attention to restoring profitability. In fact, those approaching bankruptcy experience more reporting problems (Schwartz and Soo 1995). We proxy for financial health based on ranked Altman's Z scores. Those in the lowest decile of $\mathrm{Z}$ scores (i.e., having the highest bankruptcy risk) are assigned 10 for BKRPTRANK. Clients in the next highest decile are assigned 9, and so on down to the highest $\mathrm{Z}$ score decile, coded 1 . We expect BKRPTRANK to be negatively associated with disclosure compliance.

\section{Results for firms matched on bad news}

Table 3 provides comparisons of the 64 test and 64 control firms. Since we compare matched samples, paired t-tests are conducted. Test firms have smaller average market value of equity $(p=0.058)$; the two groups contain a similar proportion of firms that have market value of equity exceeding $\$ 75$ million $(p=0.139)$. Test firm boards meet less frequently $(p=0.000)$ and are more likely to have CEOs as the board chair $(p=0.020)$. Test firms are less likely to have audit committees $(p=0.000)$, have audit committees that meet less frequently $(\mathrm{p}=0.000)$, and are less likely to have financial experts $(\mathrm{p}=$ 
Ettredge, Michael. (2011) The Effects of Company Size, Corporate Governance Quality, and Bad News on Disclosure Compliance. Review of Accounting Studies. Publisher's Official Version: <http://link.springer.com/article/10.1007\%2Fs11142-011-9153-8>. Open Access Version: http://kuscholarworks.ku.edu/dspace/.

0.017) compared to control firms. Test firms have less experienced CFOs $(p=0.098)$ and CFOs of test firms are more likely to serve on firms' boards of directors $(p=0.030)$, suggesting weaker board independence. Tests of the summary governance index show that test firms have significantly lower quality corporate governance than test firms $(\mathrm{p}=$ 0.000). Finally, test firms are less likely to have a departing Big 4 auditor $(p=0.008)$. The two groups are similar in terms of percent of independent board members, BODINDPCT, in terms of internal control material weakness, INTCONMW, and in the control variables, EXTFIN and BKRPTRANK.

[Insert Table 3 about Here]

Table 4 reports pairwise correlations, showing that FULDISC is not highly correlated with $L N M V$, but is significantly positively associated with BODMEET, AUDCOM, ACMEET, FINEXPRT, BIG4DEPART and CFOTENURE (only for Spearman correlation) and significantly negatively associated with CEOCHAIR and CFOBOD. LNMV is significantly associated with all variables except CEOCHAIR, CFOTENURE, and EXFIN. Correlations range from 0.169 (INTCONMW) to 0.515 (ACMEET), suggesting that size is a noisy corporate governance quality proxy.

[Insert Table 4 about Here]

Table 5 presents the results of estimating model (1) using the sample of 128 test and matching control firms. $L N M V$ is not significant $(\mathrm{p}=0.192)$. Size is marginally significant $(\mathrm{p}=0.093)$ when $L N M V$ is replaced with LARGE. Consistent with expectations, disclosure compliance is positively associated with board meeting frequency $(B O D M E E T, \mathrm{p}=0.060)$, the presence of an audit committee $(A U D C O M, \mathrm{p}=$ 0.041), more frequent audit committee meetings $(A C M E E T, \mathrm{p}=0.066)$, and CFOs with 
longer tenure $(C F O T E N U R E, \mathrm{p}=0.064)$. Also consistent with expectations, disclosure compliance is negatively associated with weak internal controls over financial reporting (INTCONMW, $\mathrm{p}=0.095)$. Among control variables, disclosure compliance is positively associated with external financing $(E X T F I N, \mathrm{p}=0.047)$.

[Insert Table 5 about Here]

Table 5 also presents the results of estimating model (2), in which we replace the individual governance variables with a summary variable, GOV. LNMV is insignificant. Size becomes significant and negative when $L N M V$ is replaced with LARGE (not tabulated). Further, disclosure compliance is positively associated with higher quality corporate governance $(G O V, \mathrm{p}=0.001)$; the summary measure yields the same inferences as individual components. In summary, given bad news auditor change circumstances, the disclosure of that bad news in 8-K Item 4 filings is more likely for firms with higher quality corporate governance and reliance on external financing. Size is not associated with disclosure compliance in the presence of variables that capture corporate governance quality.

\section{Additional Analyses}

6.1 Within-test-sample evidence on omission of bad news

The results of within-sample tests of association $\left(\chi^{2}\right)$ between specific types of bad news and their disclosure are mixed. ${ }^{21}$ Firms disproportionately fail to disclose some types of

\footnotetext{
${ }^{21}$ Tabled results of within sample tests will be provided upon request. ${ }^{22}$ This sample includes the 64 analyzed in section 5, plus an additional 97 that omitted required items from 8-K Item 4s, but whose omitted information did not constitute bad news.
} 
Ettredge, Michael. (2011) The Effects of Company Size, Corporate Governance Quality, and Bad News on Disclosure Compliance. Review of Accounting Studies. Publisher's Official Version: <http://link.springer.com/article/10.1007\%2Fs11142-011-9153-8>. Open Access Version: http://kuscholarworks.ku.edu/dspace/.

bad news (NOAPPROVE, EVENT, PRIORGC) but not other bad news (RESIGN, DISAGREE).

6.2 Alternative matched control sample evidence

In this section, we conduct supplementary tests using an expanded test sample that includes all 161 firms that failed to provide required 8-K Item 4 disclosures. ${ }^{22}$ We choose 161 new control firms not matched on bad news circumstances, and we add explanatory variables representing types of bad news events. The matching sample of 161 control firms both changed auditors and provided all required 8-K Item 4 disclosures. We match each test firm with the control firm whose auditor change occurred closest in time to its own, to control for time-varying environmental factors that might affect auditor change decisions. The matching process is not intended to control for test versus control firm characteristics such as firm size or bad news.

\section{[Insert Table 6 about Here]}

Columns (a) and (b) of Table 6 present descriptive statistics for the 161 test firms and the 161 matched control firms. Column '(a)-(b)' presents tests of differences in means or proportions. All p-values are based on paired t-tests. The results show that test firms are smaller $(\mathrm{p}=0.015$ and $\mathrm{p}=0.030$, respectively), and have weaker governance: fewer board meetings $(p=0.003)$, more CEOs serving as chairs of the board $(p=0.001)$, less likely to have audit committees $(p=0.000)$, fewer audit committee meetings $(p=$ $0.001)$, fewer financial experts on the boards $(p=0.005)$, more CFOs on the boards $(p=$ $0.055)$ and weaker internal controls over financial reporting $(\mathrm{p}=0.002)$. Test firms are

\footnotetext{
${ }^{22}$ This sample includes the 64 analyzed in section 5, plus an additional 97 that omitted required items from 8 -K Item $4 \mathrm{~s}$, but whose omitted information did not constitute bad news.
} 
Ettredge, Michael. (2011) The Effects of Company Size, Corporate Governance Quality, and Bad News on Disclosure Compliance. Review of Accounting Studies. Publisher's Official Version: <http://link.springer.com/article/10.1007\%2Fs11142-011-9153-8>. Open Access Version: http://kuscholarworks.ku.edu/dspace/.

also less likely to have departing Big 4 auditors $(\mathrm{p}=0.000)$, and more likely to have bad news circumstances: auditor resignation $(\mathrm{p}=0.000)$, lack of board approval of the auditor change $(p=0.000)$, more disagreement $(p=0.058)$, and prior going concern opinions (0.000). Test firms are in better financial condition than control firms.

Table 7 reports results for two models estimated with the 322 test and control firms described in Table 6. The first model includes all individual variables measuring corporate governance quality and bad news (the "component variables model"), and the second includes summary corporate governance and bad news variables (the "summary variables model").

The results concerning firm size and corporate governance quality for these two models are consistent with the results in Table 5: size (LNMV or LARGE untabulated) is not associated with compliance in the presence of variables that capture corporate governance quality. Results in the component variables model show that disclosure compliance is positively associated with the presence of an audit committee (AUDCOM, $\mathrm{p}=0.018$ ), and negatively associated with the CEO serving as chair of the board $(C E O C H A I R, \mathrm{p}=0.032)$ and internal control material weakness $($ INTCONMW, $\mathrm{p}=$ 0.092). The summary variables model reveals a positive association between disclosure compliance and corporate governance quality $(G O V, \mathrm{p}=0.017)$. The results for both models regarding bad news are consistent with within-test-sample evidence; disclosure compliance is negatively associated with $\operatorname{NOAPPROV}(\mathrm{p}=0.000)$ and PRIORGC $(\mathrm{p}=$ $0.024)$ in the component variables model, and negatively associated with $B A D(p=0.000)$ in the summary variables model. The results of these supplemental analyses using an 
alternative sample and matching procedure yield the same inferences as our analysis of firms matched on bad news.

[Insert Table 7 about Here]

\section{Limitations, summary, and conclusions}

This study assesses the incremental effects of firm size, corporate governance quality, and bad news on disclosure compliance on 8-K Item 4 filings. It is motivated by recent regulatory changes and calls for size-based disclosure regulation suggesting that firm size is an important determinant of ability to comply with accounting and disclosure requirements. To provide evidence on the factors that affect disclosure compliance, we investigate compliance with the straight-forward requirement that SEC registrants disclose information about the circumstances surrounding an auditor change. The disclosures require no computations or complex judgments but are non-routine and may require disclosure of information that previous research indicates is viewed as valuedecreasing. Our inferences regarding the lack of explanatory power of size in the presence of variables capturing corporate governance quality may not necessarily apply to other disclosure settings that do not have this characteristic. Future research could study whether size represents ability to comply in other more complex mandatory disclosure contexts.

Non-compliance related to firm size and corporate governance quality in the absence of bad news could occur because small firms lack some combination of qualified personnel and internal controls needed to ensure compliance. Although not complex, the auditor change disclosure requirements could be viewed as challenging for small firms if 
Ettredge, Michael. (2011) The Effects of Company Size, Corporate Governance Quality, and Bad News on Disclosure Compliance. Review of Accounting Studies. Publisher's Official Version: <http://link.springer.com/article/10.1007\%2Fs11142-011-9153-8>. Open Access Version: http://kuscholarworks.ku.edu/dspace/.

their personnel are not familiar with reporting requirements for infrequent events, particularly if they are served by small audit firms less familiar with non-routine SEC filing requirements.

We model compliance with auditor change disclosure requirements as a function of firm size, corporate governance quality, and whether the disclosure includes bad news that might not otherwise become public. We compare test firms that did not comply with the SEC's disclosure requirements in their 8-K Item 4 filings to several samples of control firms. We collect information about compliance from SEC staff comment letters first made public in 2005 .

Our main results and sensitivity tests indicate that firm size is not a significant determinant of compliance with auditor change disclosure requirements in the presence of variables that capture corporate governance quality. We believe these findings call into question the advisability of using firm size as the sole criterion for the imposition of or exemption from firm disclosure requirements. While an arbitrary size-cutoff provides registrants with a rule for determining applicable disclosure requirements, our results suggest that other firm characteristics would better distinguish firms that are likely to violate disclosure requirements.

Specifically, our results highlight the association between corporate governance and disclosure compliance. We find that features of the board of directors, the audit committee, and CFOs, and the strength of internal controls all are significantly associated with disclosure compliance. We find that more active boards and audit committees that meet frequently encourage disclosure compliance. We also find a positive association between disclosure compliance and both the number of financial experts on the audit 
committee and the tenure of the CFO. Thus, our results highlight the role of financial expertise and experience in assuring disclosure compliance. Finally, our results provide evidence consistent with opportunistic non-compliance in that we find that omissions of bad news are more common than omissions of good news or neutral news, particularly in situations involving failure to obtain board approval of auditor changes and disagreements with the prior audit firm. 
Ettredge, Michael. (2011) The Effects of Company Size, Corporate Governance Quality, and Bad News on Disclosure Compliance. Review of Accounting Studies. Publisher's Official Version: <http://link.springer.com/article/10.1007\%2Fs11142-011-9153-8>. Open Access Version: http://kuscholarworks.ku.edu/dspace/.

\section{References}

Abbott, L.J., Parker, S., \& Peters, G.F. (2004). Audit committee characteristics and restatements. Auditing: A Journal of Practice \& Theory, 23 (1), 69-87.

Andreoni, J., Erard, B., \& Feinstein, J. (1998). Tax compliance. Journal of Economic Literature 36 (June), 818-860.

Bedard, J., Chtourou, S. M. \& Courteau, L. (2004). The effect of audit committee expertise, independence, and activity on aggressive earnings management. Auditing: A Journal of Practice \& Theory, 23 (2), 13-35.

Bradshaw, M.T., Richardson, S.A. \& Sloan, R.G. (2006). The relation between corporate financing activities, analysts' forecasts and stock returns. Journal of Accounting and Economics, 42 (1 \& 2), 53-85.

Brickley, J.A., Cole, J.S. \& Terry, R.L. (1994). Outside directors and the adoption of poison pills. Journal of Financial Economics, 35 (3), 371-390.

Carcello, J.V. \& Neal, T. (2003). Audit committee characteristics and auditor dismissal following new going concern reports. The Accounting Review, 78 (1), 95-117.

Committee of Sponsoring Organizations of the Treadway Commission (COSO). (2004). Enterprise Risk Management --- Integrated Framework. COSO (September).

Davis, J.S., Hecht, G. \& Perkins, J.D. (2003). Social behaviors, enforcement, and tax compliance dynamics. The Accounting Review, 78 (1), 39-69.

DeFond, M., Ettredge, M. \& Smith, D. (1997). An investigation of auditor resignations. Research in Accounting Regulation, 11, 25-45.

Deloitte and Touche, LLP. (2006). CFO Center, CFO Management Framework TM www.deloitte.com.

Desai, H., Hogan, C.E. \& Wilkins, M.S. (2006). The reputational penalty for aggressive accounting: Earnings restatements and management turnover. The Accounting Review, 81 (1), 83-112.

Ettredge, M., Smith, D. \& Stone, M. (2001). How effective is joint public and private monitoring? The case of the AICPA auditor change notification letter. Auditing: A Journal of Practice \& Theory, 20 (1), 29-44.

Ettredge, M., Li, C., \& Sun, L. (2006). The impact of SOX Section 404 internal control quality assessment on audit delay in the SOX era. Auditing: A Journal of Practice \& Theory, 25 (2), 1-23. 
Ettredge, Michael. (2011) The Effects of Company Size, Corporate Governance Quality, and Bad News on Disclosure Compliance. Review of Accounting Studies. Publisher's Official Version: <http://link.springer.com/article/10.1007\%2Fs11142-011-9153-8>. Open Access Version: http://kuscholarworks.ku.edu/dspace/.

Francis, J.R. (2004). What do we know about audit quality? The British Accounting Review, 36 (4), 345-368.

Geiger, M.A. \& North, D.S. (2006). Does hiring a new CFO change things? An investigation of changes in discretionary accruals. The Accounting Review, 81 (4), 781-809.

Graham, J.R., Harvey, C.R. \& Rajgopal, S. (2005). The economic implications of corporate financial reporting. Journal of Accounting and Economics, 40 (1-3), 373.

Hackenbrack, K. \& Hogan, C. (2002). Market responses to earnings surprises conditional on reasons for an auditor change. Contemporary Accounting Research, 19 (2), $195-224$

Hammersley, J.S., Myers, L.A. \& Zhou, L. (2010). The failure to remediate previouslydisclosed material weaknesses in internal control. Working Paper. University of Georgia.

Healy, P. \& Palepu, K. (2001). Information asymmetry, corporate disclosure, and the capital markets: a review of empirical disclosure literature. Journal of Accounting and Economics, 31 (1-3), 405-440.

KPMG International. (2004). The compliance journey: Balancing risk and controls with business improvement.

KPMG International. (2005). The compliance journey: Making compliance sustainable.

KPMG LLP. (2010). Quarterly Outlook (September).

Karamanou, I., \& Vafaes, N. (2005). The association between corporate boards, audit committees, and management earnings forecasts: An empirical analysis. Journal of Accounting Research, 43 (3), 453-486.

Knapp, M., \& Elikai, F. (1988). Auditor changes: A note on the policy implications of recent analytical and empirical research. Journal of Accounting, Auditing and Finance, 3 (Winter), 78-86.

Kothari, S.P., Shu, S., \& Wysocki, P. (2009). Do managers withhold bad news? Journal of Accounting Research, 47 (1), 241-276.

Krishnan, J., \& Krishnan, J. (1997). Litigation risk and auditor resignations. The Accounting Review 72 (3), 539-560.

Li, C., Sun, L., \& Ettredge, M. (2010). CFO turnover following adverse SOX 404 opinions. Journal of Accounting and Economics, 50 (1), 93-110. 
Ettredge, Michael. (2011) The Effects of Company Size, Corporate Governance Quality, and Bad News on Disclosure Compliance. Review of Accounting Studies. Publisher's Official Version: <http://link.springer.com/article/10.1007\%2Fs11142-011-9153-8>. Open Access Version: http://kuscholarworks.ku.edu/dspace/.

Martinek, P. (2005). A year later, first batch of comment letters released. Compliance Week, (May 24).

Martinez-Vazquez, J. \& Rider, M. (2005). Multiple modes of tax evasion: Theory and evidence. National Tax Journal, 58 (1), 51-76.

Menon, K. \& Williams, J.D. (1994). The use of audit committees for monitoring. Journal of Accounting and Public Policy, 13, 121-139.

Reilly, D. (2006). Restatement Blame: Basic Mistakes. The Wall Street Journal (November 20), C4.

Sankaraguruswamy, S. \& Whisenant, J. (2004). An empirical analysis of voluntarily supplied client-auditor realignment reasons. Auditing: A Journal of Practice \& Theory, 23 (1), 107-122.

Schwartz, K.B. \& Soo, B.S. (1995). An analysis of form 8-K disclosures of auditor changes by firms approaching bankruptcy. Auditing: A Journal of Practice \& Theory, 14 (1), 125-136.

Schwartz, K.B. \& Soo, B.S. (1996). Evidence of regulatory noncompliance with SEC disclosure rules on auditor changes. The Accounting Review, 71 (4), 555-572.

SEC. (2004). SEC staff to publicly release comment letter and responses. Securities Exchange Commission Press Release No. 04-89 (June 24).

SEC Advisory Committee on Smaller Public Companies. (2006). Final report to the U.S. Securities and Exchange Commission. (April 23).

SEC. (2008). Final rule: smaller reporting companies regulatory relief and simplification act, Securities and Exchange Commission Release Nos. 33-8876; 34-56994; 392451. (January 4).

Slemrod, J., ed. (1992). Why people pay taxes: Tax compliance and enforcement. University of Michigan Press.

Smith, D.B. (1988). An investigation of Securities and Exchange Commission regulation of auditor change disclosures: the case of Accounting Series Release No. 165. Journal of Accounting Research, 26 (1), 134-145.

Weisenbach, M.S. (1988). Outside directors and CEO turnover. Journal of Financial Economics, 20, 431-460.

Wells, D. \& Loudder, M. (1997). The market effects of auditor resignations. Auditing: A Journal of Practice \& Theory, 16 (1), 138-144. 
Ettredge, Michael. (2011) The Effects of Company Size, Corporate Governance Quality, and Bad News on Disclosure Compliance.

Review of Accounting Studies. Publisher's Official Version: <http://link.springer.com/article/10.1007\%2Fs11142-011-9153-8>.

Open Access Version: http://kuscholarworks.ku.edu/dspace/.

Whisenant, J., Sankaraguruswamy, S., \& Raghunandan, K. (2003). Market reactions to disclosure of reportable events. Auditing: A Journal of Practice \& Theory, 22 (March), 181-194. 
Ettredge, Michael. (2011) The Effects of Company Size, Corporate Governance Quality, and Bad News on Disclosure Compliance. Review of Accounting Studies. Publisher's Official Version: <http://link.springer.com/article/10.1007\%2Fs11142-011-9153-8>. Open Access Version: http://kuscholarworks.ku.edu/dspace/.

Table 1 Sample disposition and industry breakdown

Panel A: Sample disposition

Initial sample of test firms receiving comment letters from the SEC

Delete: firms receiving letters citing minor issues

Delete: firms without ticker symbols

Delete: firms with missing data

Test firms receiving SEC comment letters (Section 6 analyses)

Delete: test firms that failed to disclose non-bad-news items

$\underline{(97)}$

Test firms that failed to disclose bad news items

Add: Control firms disclosing bad news

Panel B: Industry distribution by SIC codes

$\underline{\mathrm{SIC}}$

$\underline{\text { Codes }}$

01-09

Agric., Forestry, Fishing

$\underline{\mathrm{N}} \quad 0 . \underline{\%}$

10-14

Mining

$\begin{array}{ll}6 & 4.69\end{array}$

15-17

Construction

0.78

20-39

Manufacturing

1

65

50.78

40-49

Transport., Communications

4.69

50-51

Wholesale Trade

1.56

52-59

Retail Trade

1.56

60-69

Finance, Insurance, Real Estate

14.06

70-89

Service

21.09

99

Others

$\underline{0.78}$

Total

$\underline{\underline{128}}$

$\underline{\underline{100.00}}$ 
Ettredge, Michael. (2011) The Effects of Company Size, Corporate Governance Quality, and Bad News on Disclosure Compliance. Review of Accounting Studies. Publisher's Official Version: <http://link.springer.com/article/10.1007\%2Fs11142-011-9153-8>. Open Access Version: http://kuscholarworks.ku.edu/dspace/.

Table 2 Variable definitions and data sources

\begin{tabular}{|c|c|c|}
\hline Variable & Construct or proxy type & Data source \\
\hline \multicolumn{3}{|c|}{ Dependent variable } \\
\hline FULDISC & $\begin{array}{l}=1 \text { if firm disclosed all required items in its auditor-change } \\
8 \text {-K Item } 4 ; 0 \text { otherwise. }\end{array}$ & SEC, Edgar \\
\hline \multicolumn{3}{|c|}{ Proxies for bad news } \\
\hline$R E S I G N$ & $=1$ if firm's auditor resigned; 0 otherwise. & $8-\mathrm{K}$ or $8-\mathrm{K} / \mathrm{A}$ \\
\hline NOAPPROV & $=1$ if firm's board did not approve the change; 0 otherwise. & $8-\mathrm{K}$ or $8-\mathrm{K} / \mathrm{A}$ \\
\hline DISAGREE & $\begin{array}{l}=1 \text { if firm had any disagreements with its auditor; } 0 \\
\text { otherwise. }\end{array}$ & $8-\mathrm{K}$ or $8-\mathrm{K} / \mathrm{A}$ \\
\hline EVENT & $=1$ if firm had any 'reportable events'; 0 otherwise. & $8-\mathrm{K}$ or $8-\mathrm{K} / \mathrm{A}$ \\
\hline PRIORGC & $\begin{array}{l}=1 \text { if firm received a 'going concern' opinion in the prior } \\
\text { two years; } 0 \text { otherwise. }\end{array}$ & $8-\mathrm{K}$ or $8-\mathrm{K} / \mathrm{A}$ \\
\hline$B A D$ & $\begin{array}{l}=1 \text { if any of the five auditor change bad news variables are } \\
\text { coded } 1 ; 0 \text { otherwise. The bad news variables are RESIGN, } \\
\text { NOAPPROV, DISAGREE, EVENT, PRIORGC. This is a } \\
\text { summary variable capturing any kind of bad news. }\end{array}$ & $8-\mathrm{K}$ or $8-\mathrm{K} / \mathrm{A}$ \\
\hline \multicolumn{3}{|c|}{ Proxies for firm size } \\
\hline$L N M V$ & $\begin{array}{l}=\text { natural log of market value of equity at end of fiscal year } \\
\text { when } 8-\mathrm{K} \text { was issued. }\end{array}$ & Compustat \\
\hline$L A R G E$ & $\begin{array}{l}=1 \text { if firm's market value of equity exceeds } \$ 75 \text { million; } 0 \\
\text { otherwise. }\end{array}$ & Compustat \\
\hline
\end{tabular}

\section{$\underline{\text { Proxies for corporate governance quality }}$}

Board of Directors

BODINDPCT = percent of members of firm's board of directors who are

DEF14A described as independent in proxy statements.

BODMEET = number of meetings held annually by board of directors.

DEF14A

CEOCHAIR

$=1$ if CEO is the chairman of board of directors; 0

DEF14A

otherwise.

Audit committee
AUDCOM
$=1$ if firm's board of directors has an audit committee; 0
DEF14A otherwise.
ACMEET = number of meetings held annually by audit committee.
DEF14A
FINEXPRT
$=$ number of financial experts on the audit committee or the board; 0 otherwise.
Chief financial officer (CFO)
CFOTENURE = number of years CFO has held that position.
DEF14A
CFOBOD $\quad=1$ if CFO is a director; 0 otherwise.
DEF14A
INTCONMW $\quad=1$ if firm reported internal control material weakness
AuditAnalytics 
Ettredge, Michael. (2011) The Effects of Company Size, Corporate Governance Quality, and Bad News on Disclosure Compliance. Review of Accounting Studies. Publisher's Official Version: <http://link.springer.com/article/10.1007\%2Fs11142-011-9153-8>. Open Access Version: http://kuscholarworks.ku.edu/dspace/.

Table 2 continued

Summary measure of corporate governance quality

$\mathrm{GOV} \quad=$ the sum of nine indicator variables related to governance. Add one if the value of BODINDPCT, BODMEET, ACMEET, FINEXPRT or CFOTENURE is larger than sample median, respectively; add one if CEOCHAIR $=0$, $C F O B O D=0, A U D C O M=1$ and $I N T C O N M W=0$ respectively. This is a summary variable capturing various aspects of governance.

\section{External auditor class}

BIG4DEPART $=1$ if firm's departing auditor is Big 4; 0 otherwise. $\quad 8-\mathrm{K}$

\section{Control variables}

EXTFIN = the sum of equity financing and debt financing, scaled by

Compustat total assets. Equity financing equals sales of common and preferred stock minus purchases of common and preferred stock and cash dividends; debt financing equals long-term debt issued minus long-term debt reduction minus change in current debt. It is measured in the fiscal year after the auditor change.

BKRPTRANK = the decile rank of the client's Altman's Z score. Clients in the decile having the highest bankruptcy risk are assigned a value of ' 10 ' and so on down to ' 1 ' for the lowest risk decile. 
Table 3 Descriptive statistics for variables used in the section 5 logit model explaining disclosure compliance, using 64 test firms and 64 matching control firms

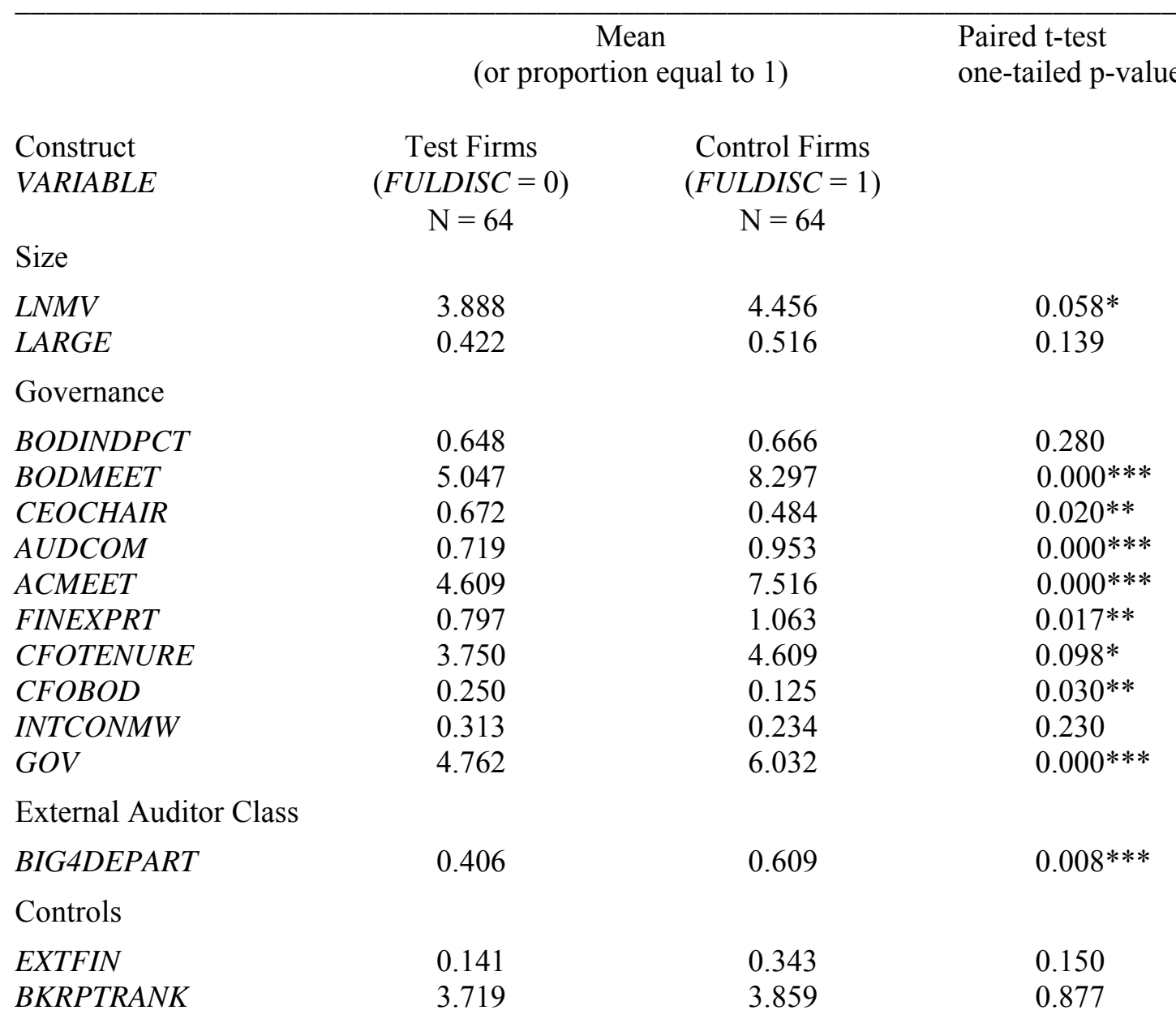

This table presents descriptive statistics for explanatory variables for 64 test firms that failed to disclose bad news conditions, and for 64 control firms that disclosed bad news.

$* * *, * *$, and * represent significance at the $0.01,0.05,0.10$ levels, respectively. All p-values are one-tailed for coefficients having the expected signs, and are two-tailed otherwise. 
Ettredge, Michael. (2011) The Effects of Company Size, Corporate Governance Quality, and Bad News on Disclosure Compliance. Review of Accounting Studies. Publisher's Official Version: <http://link.springer.com/article/10.1007\%2Fs11142-011-9153-8>

Open Access Version: http://kuscholarworks.ku.edu/dspace/.

Table 4 Correlations

\begin{tabular}{|c|c|c|c|c|c|c|c|c|c|c|c|c|c|c|c|}
\hline Variable & $\begin{array}{l}\text { FULDI } \\
\text { SC }\end{array}$ & $L N M V$ & $\begin{array}{l}\text { BODIN } \\
D P C T\end{array}$ & $\begin{array}{l}\text { BODM } \\
\text { EET }\end{array}$ & $\begin{array}{l}\text { CEOC } \\
\text { HAIR }\end{array}$ & $\begin{array}{l}\text { AUDC } \\
\text { OM }\end{array}$ & $\begin{array}{l}\text { ACME } \\
E T\end{array}$ & $\begin{array}{l}\text { FINEX } \\
P R T\end{array}$ & $\begin{array}{l}\text { CFOTE } \\
\text { NURE }\end{array}$ & $\begin{array}{l}\text { CFOB } \\
O D\end{array}$ & $\begin{array}{l}\text { INTCO } \\
\text { NMW }\end{array}$ & $\begin{array}{l}\text { BIG4D } \\
\text { EPART }\end{array}$ & EXFIN & $\begin{array}{l}\text { BKRPT } \\
\text { RANK }\end{array}$ & $G O V$ \\
\hline \multirow[t]{2}{*}{ FULDISC } & & 0.133 & 0.042 & 0.331 & -0.190 & 0.316 & 0.279 & 0.184 & 0.103 & -0.160 & -0.088 & 0.203 & 0.095 & 0.025 & 0.330 \\
\hline & & $(0.135)$ & $(0.638)$ & $(0.000)$ & $(0.032)$ & $(0.000)$ & $(0.001)$ & $(0.037)$ & $(0.246)$ & $(0.071)$ & $(0.325)$ & $(0.021)$ & $(0.287)$ & $(0.783)$ & $(0.000)$ \\
\hline \multirow[t]{2}{*}{$L N M V$} & 0.110 & & 0.367 & 0.400 & -0.020 & 0.386 & 0.515 & 0.300 & 0.067 & -0.223 & 0.169 & 0.195 & -0.140 & 0.459 & 0.487 \\
\hline & $(0.218)$ & & $(0.000)$ & $(0.000)$ & $(0.821)$ & $(0.000)$ & $(0.000)$ & $(0.001)$ & $(0.451)$ & $(0.011)$ & $(0.056)$ & $(0.028)$ & $(0.115)$ & $(0.000)$ & $(0.000)$ \\
\hline \multirow[t]{2}{*}{ BODINDPCT } & -0.032 & 0.378 & & 0.232 & 0.029 & 0.247 & 0.291 & 0.279 & -0.012 & -0.175 & 0.196 & 0.276 & -0.096 & 0.187 & 0.453 \\
\hline & $(0.718)$ & $(0.000)$ & & $(0.008)$ & $(0.743)$ & $(0.005)$ & $(0.001)$ & $(0.001)$ & $(0.896)$ & $(0.048)$ & $(0.027)$ & $(0.002)$ & $(0.281)$ & $(0.035)$ & $(0.000)$ \\
\hline \multirow[t]{2}{*}{ BODMEET } & 0.353 & 0.400 & 0.256 & & -0.215 & 0.491 & 0.497 & 0.321 & 0.072 & -0.111 & 0.105 & 0.342 & -0.124 & 0.082 & 0.624 \\
\hline & $(0.000)$ & $(0.000)$ & $(0.003)$ & & $(0.015)$ & $(0.000)$ & $(0.000)$ & $(0.000)$ & $(0.421)$ & $(0.213)$ & $(0.236)$ & $(0.000)$ & $(0.164)$ & $(0.357)$ & $(0.000)$ \\
\hline \multirow[t]{2}{*}{ CEOCHAIR } & -0.190 & -0.070 & 0.056 & -0.214 & & -0.165 & -0.069 & -0.061 & 0.227 & 0.086 & 0.063 & -0.113 & -0.052 & 0.009 & -0.291 \\
\hline & $(0.032)$ & $(0.432)$ & $(0.532)$ & $(0.015)$ & & $(0.063)$ & $(0.441)$ & $(0.491)$ & $(0.010)$ & $(0.334)$ & $(0.482)$ & $(0.203)$ & $(0.558)$ & $(0.920)$ & $(0.001)$ \\
\hline \multirow[t]{2}{*}{$A U D C O M$} & 0.316 & 0.404 & 0.207 & 0.524 & -0.165 & & 0.454 & 0.367 & 0.044 & -0.220 & 0.082 & 0.197 & -0.151 & 0.196 & 0.626 \\
\hline & $(0.000)$ & $(0.000)$ & $(0.019)$ & $(0.000)$ & $(0.063)$ & & $(0.000)$ & $(0.000)$ & $(0.618)$ & $(0.013)$ & $(0.355)$ & $(0.026)$ & $(0.088)$ & $(0.026)$ & $(0.000)$ \\
\hline \multirow[t]{2}{*}{ ACMEET } & 0.291 & 0.602 & 0.312 & 0.613 & -0.132 & 0.546 & & 0.326 & -0.003 & -0.225 & 0.134 & 0.189 & -0.177 & 0.277 & 0.600 \\
\hline & $(0.001)$ & $(0.000)$ & $(0.000)$ & $(0.000)$ & $(0.138)$ & $(0.000)$ & & $(0.000)$ & $(0.973)$ & $(0.011)$ & $(0.132)$ & $(0.033)$ & $(0.045)$ & $(0.002)$ & $(0.000)$ \\
\hline \multirow[t]{2}{*}{ FINEXPRT } & 0.179 & 0.324 & 0.309 & 0.353 & -0.041 & 0.406 & 0.453 & & -0.006 & -0.287 & 0.011 & 0.251 & -0.075 & 0.247 & 0.544 \\
\hline & $(0.043)$ & $(0.000)$ & $(0.000)$ & $(0.000)$ & $(0.646)$ & $(0.000)$ & $(0.000)$ & & $(0.945)$ & $(0.001)$ & $(0.900)$ & $(0.004)$ & $(0.399)$ & $(0.005)$ & $(0.000)$ \\
\hline \multirow[t]{2}{*}{ CFOTENURE } & 0.223 & 0.055 & 0.079 & 0.188 & 0.205 & 0.114 & 0.123 & 0.065 & & 0.075 & -0.026 & 0.031 & -0.040 & 0.008 & 0.204 \\
\hline & $(0.012)$ & $(0.534)$ & $(0.377)$ & $(0.034)$ & $(0.020)$ & $(0.200)$ & $(0.166)$ & $(0.466)$ & & $(0.397)$ & $(0.767)$ & $(0.726)$ & $(0.655)$ & $(0.925)$ & $(0.021)$ \\
\hline \multirow[t]{2}{*}{ CFOBOD } & -0.160 & -0.289 & -0.219 & -0.141 & 0.086 & -0.220 & -0.242 & -0.305 & 0.011 & & 0.020 & -0.088 & 0.038 & -0.112 & -0.505 \\
\hline & $(0.071)$ & $(0.001)$ & $(0.013)$ & $(0.112)$ & $(0.334)$ & $(0.013)$ & $(0.006)$ & $(0.000)$ & $(0.903)$ & & $(0.826)$ & $(0.326)$ & $(0.668)$ & $(0.209)$ & $(0.000)$ \\
\hline \multirow[t]{2}{*}{ INTCONMW } & -0.088 & 0.181 & 0.212 & 0.110 & 0.063 & 0.082 & 0.089 & 0.029 & -0.052 & 0.020 & & 0.043 & -0.061 & 0.137 & -0.116 \\
\hline & $(0.325)$ & $(0.040)$ & $(0.016)$ & $(0.214)$ & $(0.482)$ & $(0.355)$ & $(0.320)$ & $(0.749)$ & $(0.559)$ & $(0.826)$ & & $(0.630)$ & $(0.493)$ & $(0.122)$ & $(0.193)$ \\
\hline \multirow[t]{2}{*}{ BIG4DEPART } & 0.203 & 0.180 & 0.289 & 0.331 & -0.113 & 0.197 & 0.249 & 0.278 & 0.086 & -0.088 & 0.043 & & 0.058 & -0.051 & 0.318 \\
\hline & $(0.021)$ & $(0.042)$ & $(0.001)$ & $(0.000)$ & $(0.203)$ & $(0.026)$ & $(0.005)$ & $(0.001)$ & $(0.333)$ & $(0.326)$ & $(0.630)$ & & $(0.516)$ & $(0.569)$ & $(0.000)$ \\
\hline \multirow[t]{2}{*}{ EXFIN } & 0.008 & -0.203 & -0.196 & -0.123 & 0.035 & -0.243 & -0.264 & -0.138 & -0.161 & 0.132 & 0.018 & -0.070 & & -0.275 & -0.168 \\
\hline & $(0.928)$ & $(0.021)$ & $(0.027)$ & $(0.168)$ & $(0.692)$ & $(0.006)$ & $(0.003)$ & $(0.120)$ & $(0.070)$ & $(0.139)$ & $(0.840)$ & $(0.431)$ & & $(0.002)$ & $(0.057)$ \\
\hline \multirow[t]{2}{*}{ BKRPTRANK } & 0.031 & 0.544 & 0.221 & 0.095 & 0.016 & 0.210 & 0.279 & 0.225 & 0.044 & -0.109 & 0.144 & -0.052 & -0.291 & & 0.177 \\
\hline & $(0.727)$ & $(0.000)$ & $(0.012)$ & $(0.288)$ & $(0.854)$ & $(0.017)$ & $(0.001)$ & $(0.011)$ & $(0.621)$ & $(0.221)$ & $(0.105)$ & $(0.563)$ & $(0.001)$ & & $(0.046)$ \\
\hline \multirow[t]{2}{*}{$G O V$} & 0.306 & 0.513 & 0.465 & 0.659 & -0.283 & 0.547 & 0.724 & 0.573 & 0.337 & -0.478 & -0.124 & 0.282 & -0.316 & 0.204 & \\
\hline & $(0.000)$ & $(0.000)$ & $(0.000)$ & $(0.000)$ & $(0.001)$ & $(0.000)$ & $(0.000)$ & $(0.000)$ & $(0.000)$ & $(0.000)$ & $(0.163)$ & $(0.001)$ & $(0.000)$ & $(0.021)$ & \\
\hline
\end{tabular}

Top triangle presents Pearson correlations, and bottom triangle presents Spearman correlations. All p-values are in parenthesis and are two-tailed. 
Ettredge, Michael. (2011) The Effects of Company Size, Corporate Governance Quality, and Bad News on Disclosure Compliance. Review of Accounting Studies. Publisher's Official Version: <http://link.springer.com/article/10.1007\%2Fs11142-011-9153-8>. Open Access Version: http://kuscholarworks.ku.edu/dspace/.

Table 5 Logistic regression results explaining full disclosure of bad news in 8-K Item 4 filings

\begin{tabular}{lccccc}
\hline & & \multicolumn{2}{c}{ Model (1) } & \multicolumn{2}{c}{ Model (2) } \\
& $\begin{array}{c}\text { Predicted } \\
\text { Sign }\end{array}$ & Coeff. & p-value & Coeff. & p-value \\
Intercept & & -1.637 & $0.057^{*}$ & -2.502 & $0.000^{* * *}$ \\
LNMV & + & -0.110 & 0.192 & -0.052 & 0.324 \\
BODINDPCT & + & -0.818 & 0.248 & & \\
BODMEET & + & 0.087 & $0.060^{*}$ & & \\
CEOCHAIR & - & -0.553 & 0.104 & & \\
AUDCOM & + & 1.467 & $0.041^{* *}$ & & \\
ACMEET & + & 0.080 & $0.066^{*}$ & & \\
FINEXPRT & + & 0.064 & 0.422 & & \\
CFOTENURE & + & 0.081 & $0.064^{*}$ & & \\
CFOBOD & - & -0.613 & 0.153 & & $0.001^{* * *}$ \\
INTCONMW & - & -0.621 & $0.095^{*}$ & & \\
GOV & + & & & 0.418 & \\
BIG4DEPART & + & 0.517 & 0.121 & 0.446 & $0.068^{*}$ \\
EXTFIN & + & 0.410 & $0.047^{* *}$ & 0.363 & \\
BKRPTRANK & - & 0.030 & 0.365 & 0.025 & 0.375 \\
& & & & & \\
Number of observations & & 128 & & 0.001 & \\
Model Chi square p-value & & 0.000 & & 0.142 & \\
R-square & & 0.237 & & &
\end{tabular}

The dependent variable is FULDISC, which equals one if the firm disclosed all required items in its auditor-change 8-K Item 4; zero otherwise. The models test the association between FULDISC and variables measuring firm size, corporate governance quality, external auditor class, and controls. See Table 2 for variable definitions. Models are estimated using a sample of 64 test firms that failed to disclose bad news conditions in 8-K Item $4 \mathrm{~s}$, and 64 control firms that experienced the same bad news conditions, but disclosed them. The samples are restricted to firms having bad news to disclose, the dependent variable FULDISC captures disclosure of bad news when it is coded as one. Data in the table represent the un-standardized regression coefficients and p-values of Wald Chi-squares. All p-values are one-tailed for coefficients having the expected signs, and are two-tailed otherwise. ${ }^{* *}, * *$, and $*$ represent significance at the 0.01 , 0.05, 0.10 levels, respectively. 
Ettredge, Michael. (2011) The Effects of Company Size, Corporate Governance Quality, and Bad News on Disclosure Compliance. Review of Accounting Studies. Publisher's Official Version: <http://link.springer.com/article/10.1007\%2Fs11142-011-9153-8>. Open Access Version: http://kuscholarworks.ku.edu/dspace/.

Table 6 Descriptive statistics for variables used in section 6 logit models explaining full disclosure, using 161 test firms and two samples of control firms

\begin{tabular}{|c|c|c|c|}
\hline & \multicolumn{2}{|c|}{ Mean (or proportion equal to 1 ) } & \multirow{2}{*}{$\begin{array}{l}\text { Paired t-test } \\
\text { one-tailed p-value } \\
\text { (a)-(b) }\end{array}$} \\
\hline & $\begin{array}{l}\text { Test Firms } \\
\text { (a) }\end{array}$ & $\begin{array}{l}\text { Matched Firms } \\
\text { (b) }\end{array}$ & \\
\hline & $N=161$ & $\mathrm{~N}=161$ & \\
\hline \multicolumn{4}{|l|}{ Size } \\
\hline$L N M V$ & 3.770 & 4.285 & $0.015 * *$ \\
\hline$L A R G E$ & 0.382 & 0.485 & $0.030 * *$ \\
\hline \multicolumn{4}{|l|}{ Governance } \\
\hline BODINDPCT & 0.636 & 0.667 & 0.104 \\
\hline BODMEET & 5.448 & 6.952 & $0.003 * * *$ \\
\hline CEOCHAIR & 0.630 & 0.455 & $0.001 * * *$ \\
\hline AUDCOM & 0.721 & 0.903 & $0.000 * * *$ \\
\hline ACMEET & 4.733 & 6.515 & $0.001 * * *$ \\
\hline FINEXPRT & 0.879 & 1.103 & $0.005 * * *$ \\
\hline CFOTENURE & 3.885 & 4.200 & 0.260 \\
\hline CFOBOD & 0.255 & 0.182 & $0.055^{*}$ \\
\hline INTCONMW & 0.273 & 0.145 & $0.002 * * *$ \\
\hline GOV & 4.885 & 5.861 & $0.000 * * *$ \\
\hline \multicolumn{4}{|c|}{ External Auditor Class } \\
\hline BIG4DEPART & 0.436 & 0.648 & $0.000 * * *$ \\
\hline \multicolumn{4}{|l|}{ Bad News } \\
\hline RESIGN & 0.448 & 0.132 & $0.000 * * *$ \\
\hline NOAPPROV & 0.412 & 0.031 & $0.000 * * *$ \\
\hline DISAGREE & 0.061 & 0.025 & $0.058 *$ \\
\hline EVENT & 0.212 & 0.181 & 0.243 \\
\hline PRIORGC & 0.370 & 0.175 & $0.000 * * *$ \\
\hline$B A D$ & 0.648 & 0.297 & $0.000 * * *$ \\
\hline \multicolumn{4}{|l|}{ Controls } \\
\hline EXTFIN & -0.383 & 0.111 & 0.169 \\
\hline BKRPTRANK & 4.018 & 4.545 & $0.056^{*}$ \\
\hline
\end{tabular}

This table presents descriptive statistics for explanatory variables for 161 test firms that failed to disclose all required information in 8-K Item $4 \mathrm{~s}$ and for 161 matching control firms.

$* * *, * *$, and * represent significance at the $0.01,0.05,0.10$ levels, respectively. P-values are two-tailed. See Table 2 for variable definitions. 
Ettredge, Michael. (2011) The Effects of Company Size, Corporate Governance Quality, and Bad News on Disclosure Compliance. Review of Accounting Studies. Publisher's Official Version: <http://link.springer.com/article/10.1007\%2Fs11142-011-9153-8>. Open Access Version: http://kuscholarworks.ku.edu/dspace/.

Table 7 Logistic regression results explaining disclosure compliance in 8-K Item 4 filings using supplemental matching procedures

\begin{tabular}{|c|c|c|c|c|c|}
\hline & \multirow[b]{2}{*}{$\begin{array}{l}\text { Predicted } \\
\quad \text { Sign }\end{array}$} & \multicolumn{2}{|c|}{$\begin{array}{c}\text { Component Variables } \\
\text { Model }\end{array}$} & \multicolumn{2}{|c|}{$\begin{array}{c}\text { Summary Variables } \\
\text { Model }\end{array}$} \\
\hline & & Coeff. & p-value & Coeff. & p-value \\
\hline Intercept & & 0.976 & 0.074 & -0.259 & 0.277 \\
\hline$L N M V$ & + & -0.013 & 0.441 & -0.037 & 0.310 \\
\hline BODINDPCT & + & -1.186 & $0.067 *$ & & \\
\hline BODMEET & + & 0.008 & 0.402 & & \\
\hline CEOCHAIR & - & -0.506 & $0.032 * *$ & & \\
\hline AUDCOM & + & 0.860 & $0.018 * *$ & & \\
\hline ACMEET & + & 0.014 & 0.362 & & \\
\hline FINEXPRT & + & -0.045 & 0.414 & & \\
\hline CFOTENURE & + & -0.002 & 0.475 & & \\
\hline CFOBOD & - & -0.202 & 0.292 & & \\
\hline INTCONMW & - & -0.455 & $0.092 *$ & & \\
\hline GOV & + & & & 0.168 & $0.017 * *$ \\
\hline BIG4DEPART & + & 0.233 & 0.254 & 0.250 & 0.196 \\
\hline RESIGN & - & -0.435 & 0.124 & & \\
\hline NOAPPROV & - & -2.594 & $0.000 * * *$ & & \\
\hline DISAGREE & - & -0.326 & 0.328 & & \\
\hline EVENT & - & -0.226 & 0.271 & & \\
\hline PRIORGC & - & -0.702 & $0.024 * *$ & & \\
\hline$B A D$ & - & & & -1.279 & $0.000 * * *$ \\
\hline EXTFIN & + & -0.001 & 0.492 & 0.013 & 0.381 \\
\hline BKRPTRANK & - & 0.020 & 0.347 & 0.029 & 0.256 \\
\hline $\begin{array}{l}\text { Number of } \\
\text { observations }\end{array}$ & & 322 & & & 322 \\
\hline $\begin{array}{l}\text { Model Chi square p- } \\
\text { value }\end{array}$ & & 0.000 & & & 0.000 \\
\hline R-square & & 0.280 & & & 0.140 \\
\hline
\end{tabular}

The dependent variable is FULDISC, which equals one if the firm disclosed all required items in its auditor-change 8-K Item 4; zero otherwise. The models test the association between FULDISC and variables measuring firm size, corporate governance quality, departing auditor class, and controls. See Table 2 for variable definitions. The components variable model employs all available proxies for quality of governance and bad news as explanatory variables. The summary variables model replaces the bad news and governance proxies with summary variables $B A D$ and GOV. Models are estimated using a sample of 161 test firms that failed to disclose required information in 8-K Item 4s, and 161 matching control firms that changed auditors on approximately the same dates, but disclosed all required items. Data in the table represent the unstandardized regression coefficients and p-values of Wald Chi-squares. All p-values are onetailed for coefficients having the expected signs, and are two-tailed otherwise. $* * *, * *$, and * represent significance at the $0.01,0.05,0.10$ levels, respectively. 